\title{
The response of corn (Zea mays L.) cultivars to row spacing under weed interference condition
}

\author{
Gholamreza MOHAMMADI ${ }^{1}$, Mehdi NOOKANI ${ }^{2}$, Hamidreza MOHAMMADDOUST $^{2}$, Danial KAHRIZI $^{1}$
}

Received May 10, 2018; accepted October 23, 2018.

Delo je prispelo 10. maja 2018, sprejeto 23. oktobra 2018.

\begin{abstract}
This study was carried out in order to study the response of corn cultivars to row spacing and weed interference at the Research Farm of Agricultural and Natural Resources Faculty, Razi University, Kermanshah, Iran in 2011. The experiment was a split block factorial based on a randomized complete block design with three replications. Factors consisted of three corn cultivars ('KSC 704', 'Simon' and 'Maxima') and three plant row spacings $(45,60$ and $75 \mathrm{~cm})$ under weeded and unweeded conditions for all of the growing season. Results indicated that for all three corn cultivars, the highest weed dry mass occurred in the row spacing of $75 \mathrm{~cm}$. Weed interference throughout the growing season reduced corn grain yield by $20 \%$. This condition also significantly decreased corn yield components except the 100-seed mass. Increasing plant row spacing increased weed density, while decreased corn yield by $16.5 \%$. Corn cultivars were significantly different in terms of the number of seed per ear and 100-seed mass, as 'KSC 704' and 'Simon' showed the highest values for these yield components, respectively. However, the number of ear per plant and grain yield were not significantly different between the corn cultivars under study.
\end{abstract}

Key words: corn; competition; 'KSC 704'; 'Maxima'; 'Simon'; weed; yield; yield component

\section{IZVLEČEK}

ODZIV SORT KORUZE (Zea mays L.) NA RAZMIK
MED SETVENIMI VRSTAMI IN VPLIV PLEVELA

$\mathrm{V}$ raziskavi je bil preučevan vpliv razmika med setvenimi vrstami in zapleveljenostjo pri treh sortah koruze na Research Farm of Agricultural and Natural Resources Faculty, Razi University, Kermanshah, Iran, v letu 2011. Poskus je bil izveden kot popolni naključni bločni poskus z deljenkami s tremi ponovitvami. Faktorje so predstavljali tri sorte koruze ('KSC 704', 'Simon' in 'Maxima') in trije razmiki med setvenimi vrstami $(45,60$ in $75 \mathrm{~cm}) \mathrm{v}$ razmerah brez plevela in s plevelom v celotni rastni sezoni. Rezultati so pokazali, da je bila največja masa plevelov pri vseh treh sortah pri razmiku setvenih vrst $75 \mathrm{~cm}$. Zapleveljenost skozi celotno rastno sezono je zmanjšala pridelek zrnja koruze za $20 \%$. Te razmere so tudi značilno zmanjšale posamezne komponente pridelka razen mase 100-zrn. Povečan razmik med vrstami je povečal gostoto plevela, kar je zmanjšalo pridelek koruze za $16.5 \%$. Sorte koruze so se značilno razlikovale v številu zrn na storž in v masi 100-zrn, pri čemer sta imeli 'KSC 704' in 'Simon' največji vrednosti teh dveh komponent pridelka.Kljub temu se število storžev na rastlino in pridelek zrnja nista statistično značilno raziskovala med sortami, preučevanimi $\mathrm{v}$ tej raziskavi.

Ključne besede: koruza; kompeticija; 'KSC 704'; 'Maxima'; 'Simon'; plevel; pridelek; komponente pridelka

\section{INTRODUCTION}

Corn is one of the most important crops which is extensively planted in Iran and Kermanshah province is proposed as a major region to produce this crop. Weed interference is a main limiting factor which can significantly reduce corn yield and economic return. The reduction may range from 30 to $70 \%$ when weeds are not controlled during the growing season (Ford and Mt Pleasant, 1994; Teasdale, 1995; Mohammadi 2010; Mohammadi et al., 2012b).In many regions of Iran such as Kermanshah, farmers highly use chemical and mechanical methods to control weeds in their corn production systems. These methods usually have

1 Dept. of Plant Production and Genetics, College of Agriculture and Natural Resources, Razi University, Kermanshah, Iran; *corresponding author: mohammadi114@yahoo.com

2 Dept. of Crop Production and Breeding, Faculty of Agricultural Sciences, University of MohagheghArdabili, Ardabil, Iran 
negative environmental consequences (such as soil erosion, water and soil pollution) and notably increase the cost of corn production.

Alteration of planting arrangement has been documented as an efficient approach to suppress weeds in agroecosystems (Mohammadiet al., 2015) which can be achieved by a reduced row spacing.Vera et al. (2006) suggested that narrower row spacings can cause an earlier canopy closure and allow the crop to shade weeds in their early developmental stages. Other researchers working with barley showed that increasing seeding rate and the use of high competitive cultivars improved crop competitiveness against weeds (Watson et al., 2006; Harker et al., 2009). This can be due toan increased resource use by crop which can lead to the reduced effects of weeds (Berkowitz, 1988; Mohler, 1996). Chauhain and Johnson (2011) reported that rice grown in narrower rows had higher grain yield and lower weed biomass than in wider rows and increasing row spacing caused more crop vulnerability to weed competition for the longest period. Drews et al. (2004) also found that the competitive ability of short-stature cultivars could be improved by reducing row spacing.
Weed competition to acquire limited resources is the primary cause for crop yield loss from weeds. Crop cultivars with high weed competitive abilities may be used in an integrated weed management (IWM) program (Lemerle et al., 1996; Lindquist and Kropff, 1996). Some studies have shown that corn cultivars differ in terms of their ability to suppress weeds (Mohammadi, 2007; So et al., 2009). Identification of these cultivars can significantly improve crop yield in the presence of weeds and reduce the cost and environmental consequences caused by weed control practices. According to McDonald (2003) the development of crop cultivars with high competitive abilities against weeds is an important aspect of IWM and can decrease the reliance of cropping systems to chemical herbicides.

The main objective of this study was to evaluate the response of some corn cultivars to different row spacings under weed interference condition at Kermanshah, west Iran.

\section{MATERIALS AND METHODS}

The study was carried out at the Research Farm of Agricultural and Natural Resources Faculty, Razi University, Kermanshah (latitude $34^{\circ} 18^{\prime} \mathrm{N}$, longitude $47^{\circ} 4^{\prime} \mathrm{E}$, altitude 1350 asl), Iranin 2011. Soil was a clayloam with a $\mathrm{pH}$ of 8 and $1.4 \%$ organic matter. The experiment was a factorial split block based on a randomized complete block design with three replications. The first factor was corn cultivars including 'KSC 704' (late matured), 'Simon' and 'Maxima' (both medium-matured cultivars) which are cultivars well-adapted to the environmental conditions of the region. The second factor was three plant row spacings including conventional $(75 \mathrm{~cm})$ and reduced (45 and $60 \mathrm{~cm})$. To evaluate weed interference effect on corn plant traits each block was divided into two sections lengthways, which one of them was kept free of weeds and another was un-weeded for all of the growing season. There was a dense natural weed infestation in the experimental field. The list of dominant weed species is shown in Table 1.

The land was plowed then disked before planting. Fertilizers were applied according to the soil test recommendations. Corn was planted on May 2011.
Each plot consisted of 6 rows (6 m per row) with a planting density of 6.5 plant $\mathrm{m}^{-2}$. Weeds werehand weeded in weed-free section of each plot throughout the growing season. At maturity, the corn ears belong to the two center rows of each plot were harvested by hand, allowed to dry toa constant mass then threshed and grain yield was determined. Corn yield components including the number of ears per plant and the number of seeds per ear were determined on ten randomly selected plants of each plot. Additionally, 100grainmass was calculated according to the recommendations of the International Seed Testing Association (ISTA) (Draper, 1985).

At the end of the growing season, weed density and dry masswere determined by harvesting weeds at ground level in two random $0.5 \times 0.5 \mathrm{~m}$ squaresin un-weeded section of each plot. Weeds were initially counted then dried at $80^{\circ} \mathrm{C}$ to a constant mass then weighed. Data analyses including analysis of variance and mean comparison were carried out using SAS software (SAS Institute, 2003). Means were compared using Duncan test at the 0.05 level of probability. 
Table 1: The list of dominant weed species emerged in the experimental field

\begin{tabular}{l|l}
\hline Common name & Scientific name \\
\hline Johnsongrass & Sorghum halepense $(\mathrm{L}$.$) Pers.$ \\
Redroot pigweed & Amaranthus retroflexus $\mathrm{L}$. \\
Lamb'squarters & Chenopodium album $\mathrm{L}$. \\
Common cocklebur & Xanthium strumarium $\mathrm{L}$. \\
Field bindweed & Convolvulus arvensis $\mathrm{L}$. \\
Common purslane & Portulaca oleracea $\mathrm{L}$. \\
\hline
\end{tabular}

\section{RESULTS AND DISCUSSION}

\subsection{Weed density}

Analysis of variance (data not shown) revealed that weed density (WD) was significantly influenced by row spacing. Weed density reduced in response to decreasing row spacing as the highest WD occurred in the conventional row spacing $(75 \mathrm{~cm})$. Although, there was no significant difference between the two reduced row spacings (45 and $60 \mathrm{~cm}$ ) in terms of WD (Fig. 1).Reduction of WD in narrower rows can be attributed to an earlier canopy closure and consequently a less light level intercepted by weed seeds. Some studies showed that an earlier canopy closure can notably reduce weed germination and emergence by decreasing light quantity (intensity) and quality (spectrum)reaching the soil surface under the canopy (Bradley, 2006; Ghadiri and Bayat, 2004; Rajcan and Swanton, 2001).

Lindquist and Mortensen (1999) also reported that a reduced row spacing can improve weed control in corn due to an earlier crop canopy closure. According to Porter et al. (1997) compared to wider rows $(76.2 \mathrm{~cm}) \mathrm{a}$ reduced row spacing $(50.8 \mathrm{~cm})$ decreased the light penetrated into the crop canopy by $10 \%$ causing a $35 \%$ decrease in weed infestation.

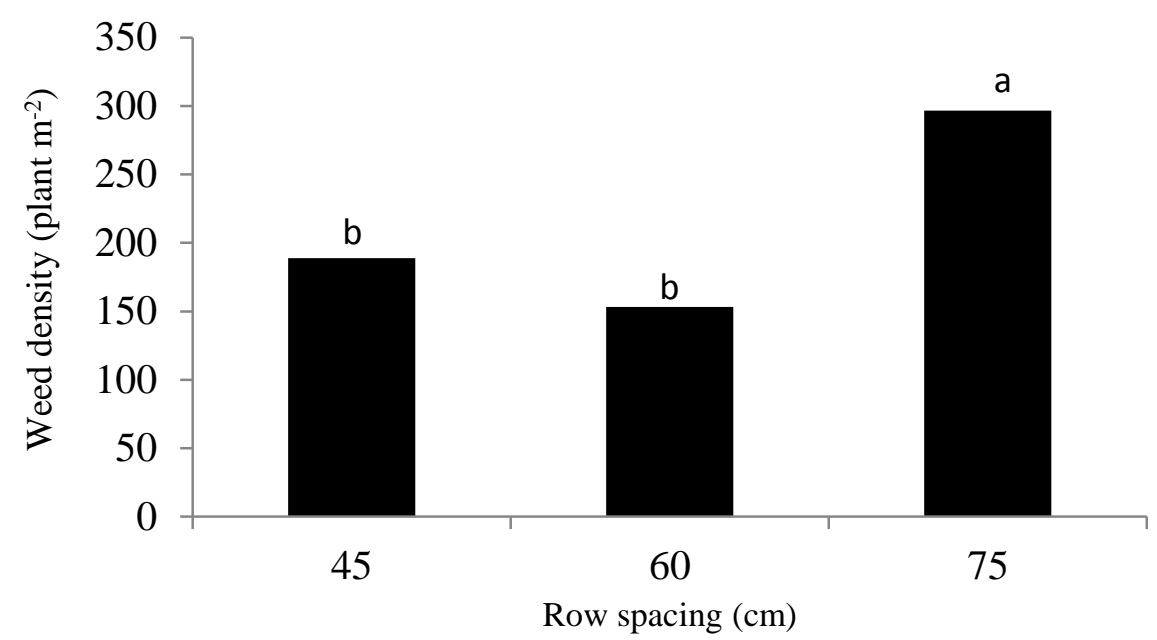

Figure 1: The effect of corn planting row spacing on weed density. The same letters show non significant difference at the 0.05 level of probability

\subsection{Weed dry mass}

There was a significant two-way interaction (cultivar $\times$ row spacing) for weed dry mass (WDM). A notable higher WDM was observed in the conventional row spacing $(75 \mathrm{~cm})$ compared to the narrower rows $(45$ and $60 \mathrm{~cm}$ ) (Fig. 2). Although, there was no significant differences between these two reduced row spacings with regard to WDM. It seems that reduced row spacing can cause a more equidistant plant distribution in the field and consequently higher efficient use of the environmental resources by crop plants which lead to a 
higher weed suppressing ability. In contrast, wider rows can intensify intra-specific competition between crop plants and provide a suitable space to weed growth between rows (Akbari et al., 2011). A reduced weed dry massproduced due to narrower rows was reported by Johnson and Haverstad (2002). Mohammadi et al. (2012a) also observed a $49.4 \%$ decrease in weed biomass in response to reduced row spacing and increased planting density.

Corn cultivars also showed different negative effects on WDMin relation to row spacing (Fig. 2). At the lowest row spacing $(45 \mathrm{~cm})$ 'Maxima' had higher weed suppressing effect than other two cultivars. However, there were no significant differences between the cultivars at the wider rows in terms of WDM (Fig. 2). According to Mohammadi (2007) corn cultivars differed in their competitive ability against weeds and the cultivars with higher relative growth rate and specific leaf area performed better than others. Similar results have been reported by So et al. (2009) working with sweet corn.

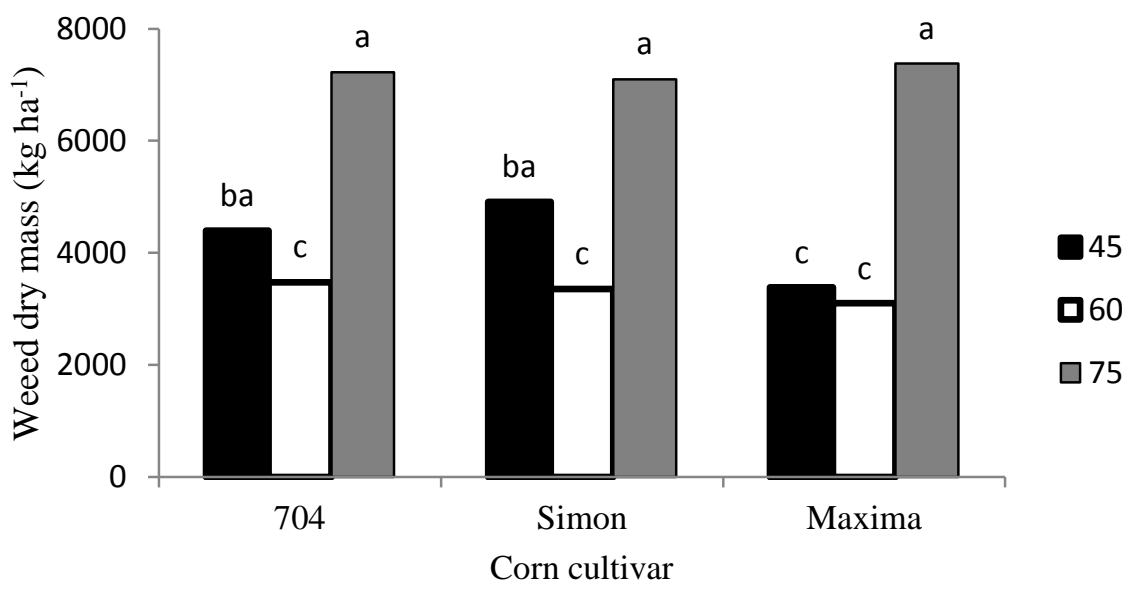

Figure 2: The effect of corn cultivar on weed dry mass under different row spacing. The same letters show non significant difference at the 0.05 level of probability

\subsection{Corn yield components}

The number of ear per plant (NEP) was significantly influenced by weed interference. However, cultivar and row spacing didn't show significant effects on this trait. Full season weed interference reduced NEP by $4.9 \%$ (Fig. 3). This occurred due to the failure of some corn plants to form ear in the presence of competing weeds. However, NEP didn't show significant response to row spacing or cultivars. Other workers also suggested that row spacing didn't have a notable effect on the number of ear per plant (Turgut et al., 2005; Mohammadi etal., 2012a).

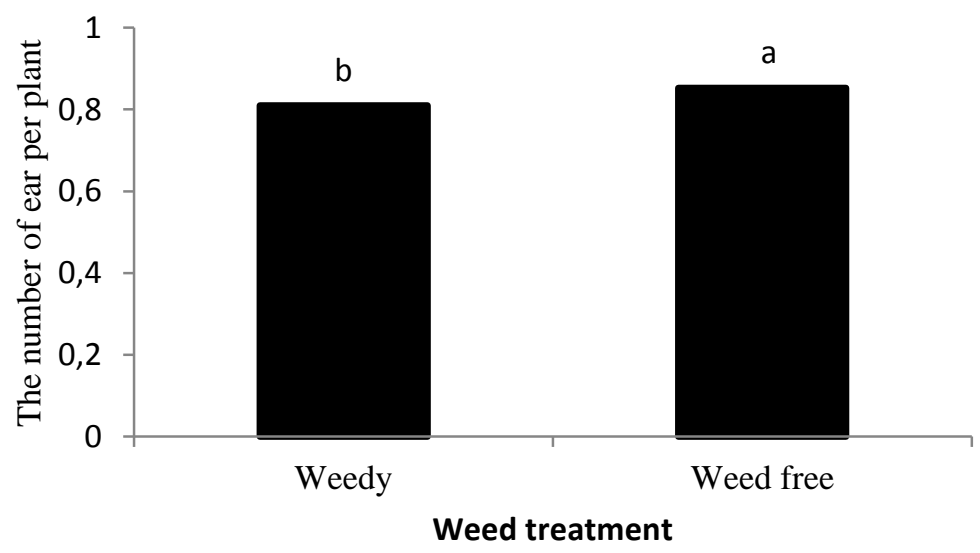

Figure 3: The effect of weed interference on the number of ears per plant of corn. The same letters show non significant difference at the 0.05 level of probability 
Weed interference and corn cultivar showed significant effects on the number of seeds per ear (NSE). 'KSC 704' had a significant higher NSE (600 seeds per ear) followed by 'Maxima' and "Simon'which showed lower and non significantdifferent NSE (Fig. 4). Weed interference for the entire growing season reduced NSE by $15.8 \%$ as compared with weed free condition (Fig.
5). Similar result was reported by Mohammadi et al. (2012b) who reported a $23 \%$ reduction in NSE resulted from a full season weedy condition. This may be due to a less number of fertilized florets per ear caused by weed competition. Evans et al. (2003) found a sigmoidal reduction in the number of seeds per ear in response to increasing weed interference period in corn.

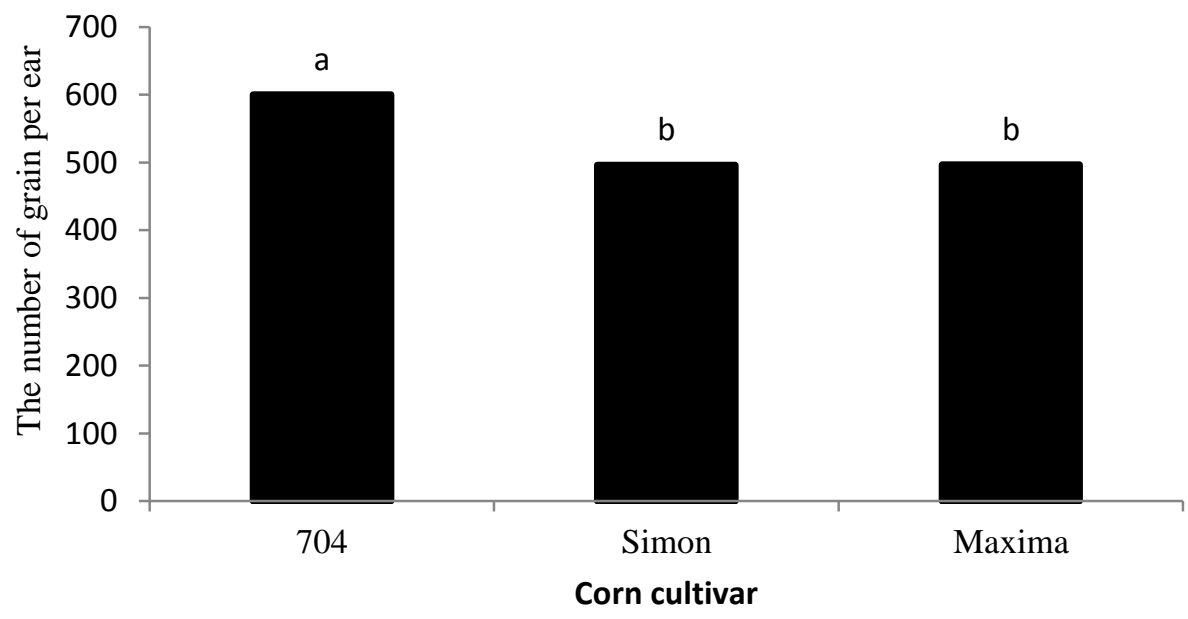

Figure 4: The effect on the number of grain per ear of corn. The same letters show non significant difference at the 0.05 level of probability

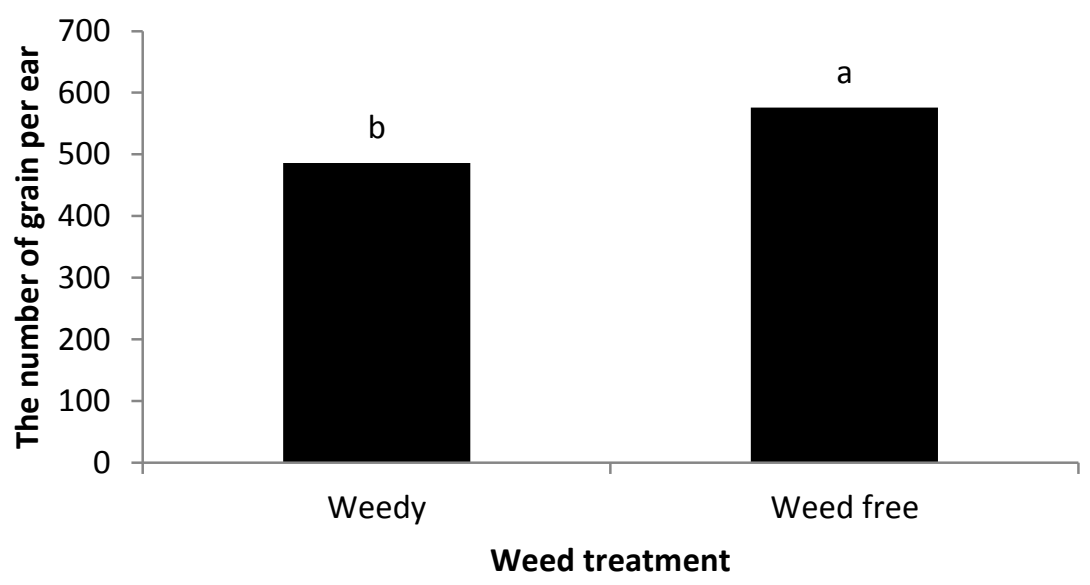

Figure 5: The effect of weed interference on the number of grain per ear of corn. The same letters show non significant difference at the 0.05 level of probability

100-grain yield (100-GM) was significantly affected by corn cultivar and row spacing. The highest 100-GM belonged to 'Simon' followed by 'Maxima' and 'KSC 704' (Fig. 6). However, there was no significant difference between 'Maxima' and other two cultivars in terms of 100-grain mass (Fig. 6). 100-grain mass showed a positive response to decreasing row spacing as this yield component was notably higher in the narrower rows (45 and $60 \mathrm{~cm}$ ) compared to conventional row spacing $(75 \mathrm{~cm})$ (Fig. 7). This can be resulted from a more equidistantdistribution of corn plants and a lower intra-specific competition between them which consequently led to a more efficient use of the environmental resources. 


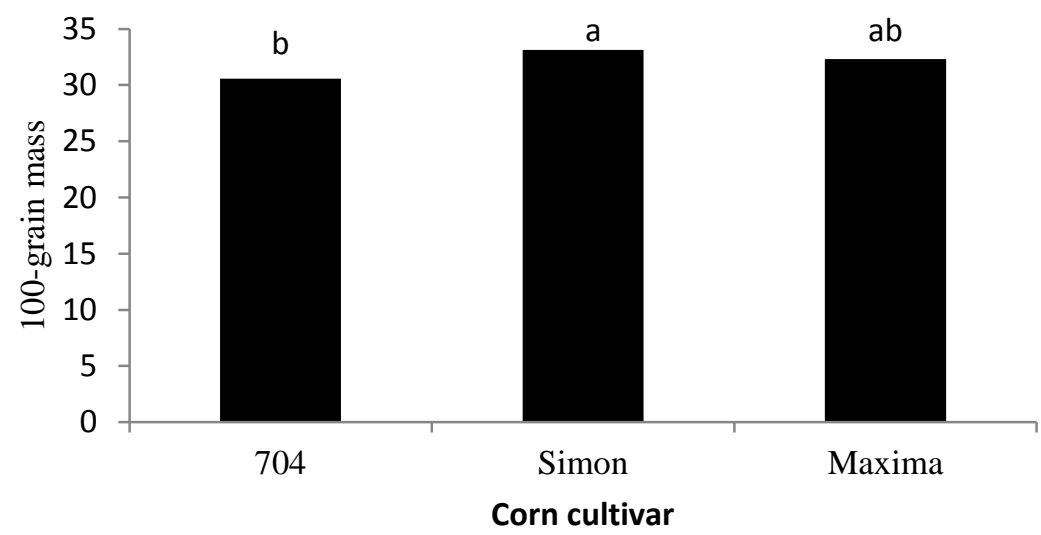

Figure 6: The effect cultivar on corn grain mass. The same letters show non significant difference at the 0.05 level of probability

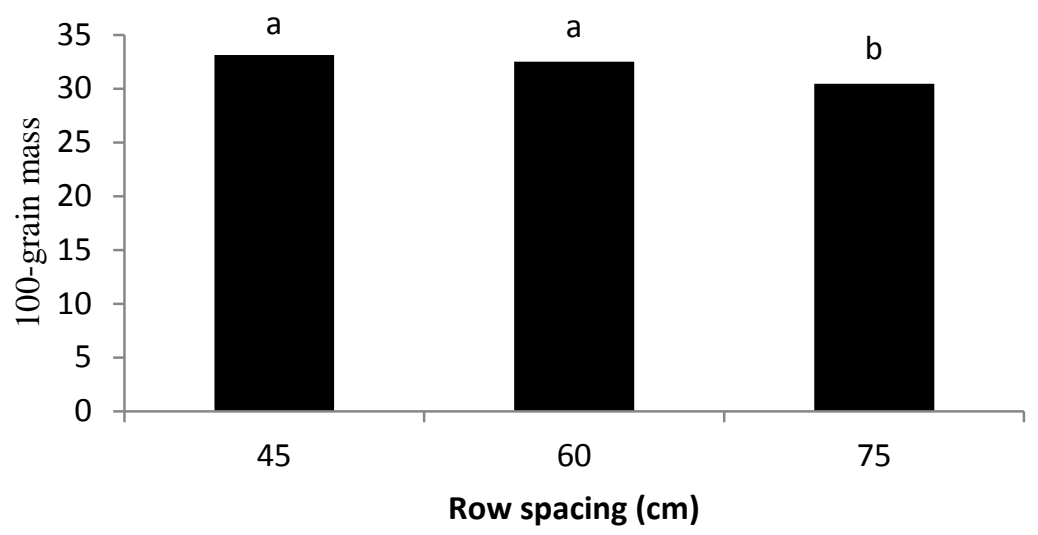

Figure 7: The effect of row spacing on 100-grain mass of corn. The same letters show non significant difference at the 0.05 level of probability

Weed interference had no significant effect on 100-GM. This is in contrast with Mohammadi (2010) who reported that 100-GM was negatively affected by competing weeds. No significant influence of weeds on $100-$ GM can be due to a lower grains produced per ear under weed stress condition (Fig. 5). In other words, it can be expected in this condition the number of grains formed in each ear to be balancedwith the available resources which led to a less vulnerability of 100-GM to weed interference

\subsection{Corn grain yield}

Corn grain yield showed significant responses to row spacing and weed interference. A $1000 \mathrm{~kg} \mathrm{ha}^{-1}$ increase in grain yield was observed when row spacing decreased from 75 to $45 \mathrm{~cm}$ (Fig. 8). This is compatible with Mohammadi et al. (2012a) who reported a $19.7 \%$ increase in corn yield in response to decreasing row spacing from 75 to $50 \mathrm{~cm}$. This can be explained by a more equidistant plant arrangement in narrower rows which consequently lead to a lower intra-specific competition and improved use of environmental resources by corn plants (Andrade et al., 2002; Barbieri et al., 2008). Bullock et al. (1988) also reported that increasing corn grain yield in reduced row spacings was due to more suitable plant distribution perunit area and consequently a lower competition between plants to acquire light, soil nutrient and moisture. 


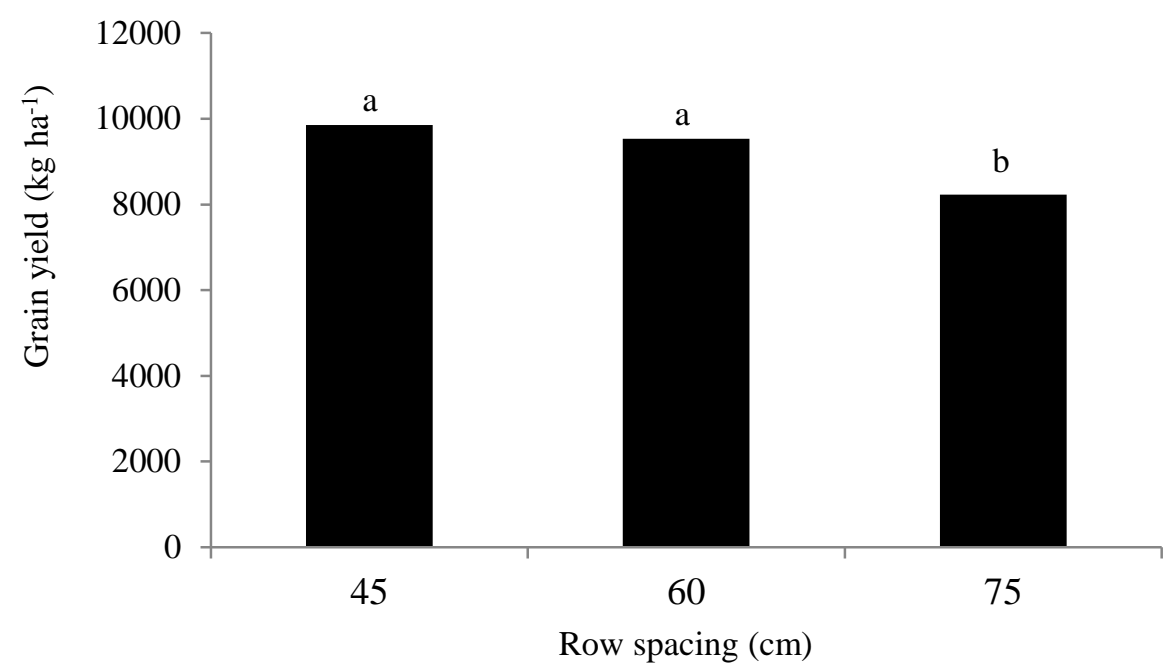

Figure 8: The effect of row spacing on corn grain yield. The same letters show non significant difference at the 0.05 level of probability

Weed interference decreased grain yield by $20 \%$ (Fig. 9). Reduced crop yield in response to weed interference has been reported by other workers. Habibisavadkoohi et al. (2008) found a $60 \%$ decrease in corn yield when weeds interfered with corn for a long period. In other studies the reductions of 30.7 and $41.1 \%$ were reported for corn grain yield in full season weedy condition (Mohammadi, 2010; Mohammadi et al., 2012b). In general, weeds reduce crop yield via competition to obtain essential growth resources and releasing allelochemicals into the environment.

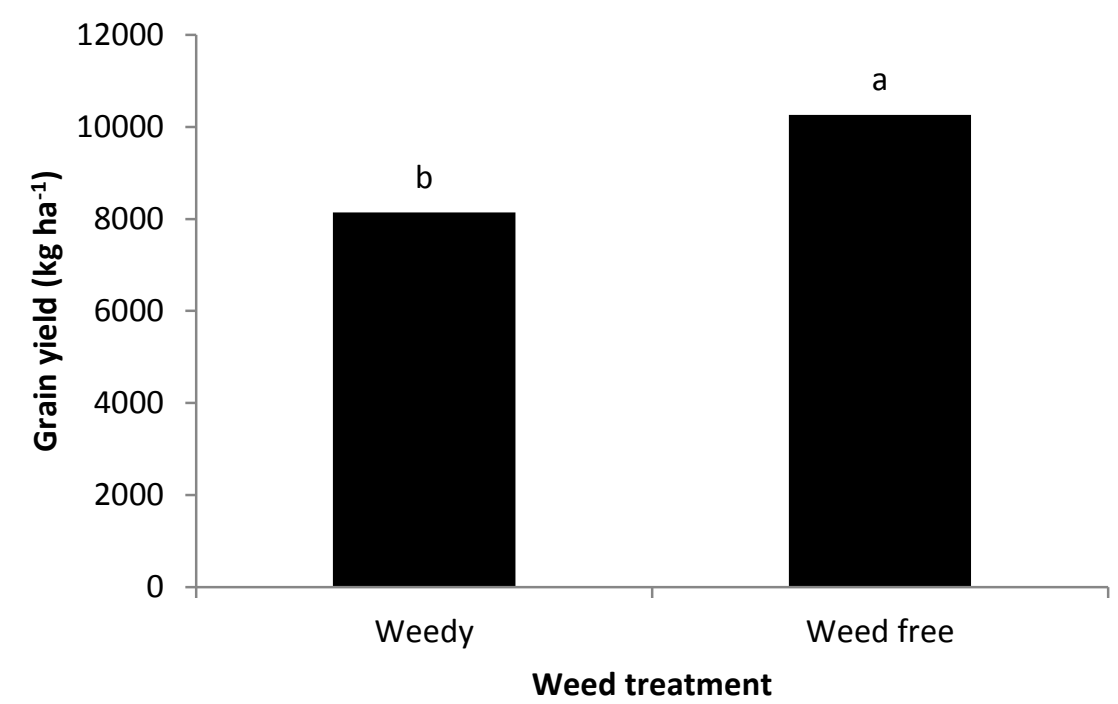

Figure 9: The effect of weed interference on corn grain yield. The same letters show non significant difference at the 0.05 level of probability 


\section{CONCLUSION}

This study revealed that in comparison with the conventional plant row spacing $(75 \mathrm{~cm})$ narrower rows improved corn yield. These improvements were 16.5 and $13.6 \%$ for the row spacings of 45 and $60 \mathrm{~cm}$, respectively. This can be related to a more equidistant plant distribution pattern and reduced intra-specific competition between corn plants which consequently lead to a more efficient use of the environmental resources. The narrower rows also reduced weed biomass and density. This can be attributed to the improved growth of corn plants and their competitive ability against weeds probably due to an earlier canopy closure under this condition.

\section{REFERENCES}

Akbari, A., Zand E. and Mousavi, S. K. (2011). Evaluation the effect of row space and weed management approaches on biomass, chickpea (Cicer arietinum L.) yield, and yield components in Khorramabad dryland conditions. Electronic Journal of Crop Production,3, 1-21.

Andrade, F. H., Calvino, P., Cirilo, A. and Barbieri, P. (2002). Yield responsesto narrow rows depend on increased radiation interception. Agronomy Journal, 94, 975-980. doi:10.2134/agronj2002.0975

Barbieri, P. A., Echeverría, H. E., SaínzRozas, H. R. and Andrade, F. H. (2008). Nitrogen use efficiency in maize as affected by nitrogen availability and row spacing. Agronomy Journal,100, 1094-1100. doi:10.2134/agronj2006.0057

Berkowitz, A. R. (1988). Competition for resources in weed-crop mixtures.Pages 89-119 in M. A. Altieri and M. Liebman, eds. Weed management in agroecosystems: Ecological approaches. CRC Press, Inc., Boca Raton, FL.

Bradley, K. W. (2006). A review of the effects of row spacing on weed management in corn and soybean.[Online], Available at www.plant management network.org/cm/. Crop Management, doi:10.1094/CM-2006-0227-02-RV

Bullock, D. G., Nielson, R. L. and Nyquist, W. E. (1988). A growth analysis comparison of corn grown in conventional and equidistant plant spacings. Crop Science, 28, 254-258. doi:10.2135/cropsci1988.0011183X002800020015 $\mathrm{X}$

Chauhan B. S. and Johnson D. E. (2011). Row spacing and weed control timing affect yield of aerobic rice. Field Crops Research, 121, 226-231. doi:10.1016/j.fcr.2010.12.008

Draper, S. R. (1985). International rules for seed testing. Seed Science and Technology, 13, 342-343.

Drews S., Juroszek P., Neuhoff D., Kopke U. (2004). Optimizing shading ability of winter wheat stands as a method of weed control. Journal of Plant Diseases and Protection, 19, 545-552.

Evans, S. P., Kenezevic, Z. S., Lindquist, J. L., Shapiro, C. A. and Blankenship, E. E. (2003). Nitrogen application influences the critical period for weed control in corn. Weed Science, 15, 408-417. doi:10.1614/00431745(2003)051[0408:NAITCP]2.0.CO;2

Ford, G. T. and Mt Pleasant, J. (1994). Competitive abilities of six corn (Zea mays L.) hybrids with four weed control practices. Weed Technology, 8, 124128. doi:10.1017/S0890037X00039312

Ghadiri, H. and Bayat, M. L. (2004). Effect of row and plant spacing on weed competition with Pinto Beans (Phaseolus vulgaris L.). Journal of Agricultural Science and Technology, 6, 1-9.

Habibisavadkoohi, M., Pirdashti, H., Amini, I., Abbasian, A. and Keramati, S. (2008). Effect of weeding time on the species composition, plant density, dry weight and physiological traits of weeds in corn (Zea mays L.). Iranian Society of Weed Science, 2, 9-21.

Harker, K. N., O’Donovan J. T., Irvine R. B., Turkington T. K., and Clayton G. W. (2009). Integrating cropping systems with cultural techniques augments wild oat (Avena fatua) management in barley. Weed Science, 57, 326-337. doi:10.1614/WS-08-165.1

Johnson, G. A. and Haverstad, T. R. (2002). Effect of row spacing and herbicide application timing on weed control and grain yield in corn (Zea mays L.). Weed Technology, 16, 548-553. doi:10.1614/0890037X(2002)016[0548:EORSAH]2.0.CO;2

Lemerle, D., Verbeek, B., Cousens, R. D., Coombes, N. E. (1996). The potential for selecting wheat varieties strongly competitive against weeds. Weed Research, 36, 505-513. doi:10.1111/j.13653180.1996.tb01679.x 
Lindquist, J. L. and Kropff M. J. (1996). Applications of an ecophysiological model for irrigated rice (Oryza sativa)_Echinochloacompetition. Weed Science, 44, 52-56.

Lindquist, J. L. and Mortensen, D. A. (1999). Tolerance and velvet leaf (Abutilon theophrasti) suppressive ability of two old and two modern corn (Zea mays) hybrids. Weed Science, 46, 569-574.

McDonald, G. K. (2003). Competitiveness against grass weeds in field pea genotypes. Weed Research, 43, 48-58. doi:10.1046/j.1365-3180.2003.00316.x

Mohammadi, G. R. (2007). Growth parameters enhancing the competitive ability of corn (Zea mays L.) against weeds. Weed Biology and Management, 7, 232-236. doi:10.1111/j.14456664.2007.00261.x

Mohammadi, G. R. (2010). Weed control in irrigated corn by hairy vetch interseeded at different rates and times. Weed Biology and Management, 10, 2532. doi:10.1111/j.1445-6664.2010.00363.x

Mohammadi, G. R., Chatrnour, S., Jalali-honarmand, S. and Kahriz, D. (2015). The effects of planting arrangement and phosphate biofertilizer on soybean under different weed interference periods. Acta Agriculturae Slovenica, 105, 313 - 322. doi:10.14720/aas.2015.105.2.14

Mohammadi, G. R., Ghobadi, M. E. and Sheikheh poor, S. (2012a). Phosphate biofertilizer, row spacing and plant density effects on corn (Zea mays L.) yield and weed growth. American Journal of Plant Science, 3, 425-429. doi:10.4236/ajps.2012.34051

Mohammadi, G. R., Mozafari, S., Ghobadi, M. E. and Najaphy, A. (2012b). Interaction effects of weed interference and berseem clover (Trifolium alexandrinum) as a living mulch on corn (Zea mays). Advances in Environmental Biology, 6, 763767.

Mohler, C. L. (1996). Ecological bases for the cultural control of annual weeds. Journal of Production Agriculture, 9, 468-474. doi:10.2134/jpa1996.0468
Porter, P. M. and Hicks, D. R., Lueschen, W. E., Ford, J. H., Warnes, D. D. and Hoverstad, T. R. (1997). Corn response to row width and plant population in the Northern Corn Belt. Journal of Production Agriculture, $\quad 10, \quad 293-300$. doi:10.2134/jpa1997.0293

Rajcan, I. and Swanton C. J. (2001). Understanding maize-weed competition:resource competition, light quality and the whole plant. Field Crops Research, 71, 139-150. doi:10.1016/S03784290(01)00159-9

SAS Institute (2003). SAS/STAT. User's Guide.Version 9.1. SAS Inst., Inc., Cary, NC.

So, Y. F., Williams M. M., Pataky J. K., and Davis A. S. (2009). Principal canopy factors of sweet corn and relationships to competitive ability with wildproso millet (Panicum miliaceum). Weed Science, 57, 296-303. doi:10.1614/WS-08-158.1

Teasdale, J. R. (1995). Influence of narrow row/high population corn (Zea mays) on weed control and light transmittance. Weed Technology, 9, 113-118. doi:10.1017/S0890037X00023046

Turgut, I., Duman, A., Bilgili, U. and Acikgoz, E. (2005). Alternate row spacing and plant density effects on forage and dry matter yield of corn hybrids (Zea mays L.). Journal of Agronomy and Crop Science, 191, 146-151. doi:10.1111/j.1439037X.2004.00146.X

Vera C. L., Woods S. M. and Raney J. P. (2006). Seeding rate and row spacing effect onweed competition, yield and quality of hemp in the Parkland region of Saskatchewan. Canadian Journal of Plant Science, 86, 911-915. doi:10.4141/P05-177

Watson, P. R., D. A. Derksen, and Van Acker R. C. (2006). The ability of 29 barley cultivars to compete and withstand competition. Weed Science, 54, 783-792. doi:10.1614/WS-05-020R3.1 